\title{
Energy efficiency of high-rise buildings
}

\author{
Anna Yu. Zhigulina $^{1 *}$, Alla M. Ponomarenko ${ }^{1}$ \\ ${ }^{1}$ Samara State Technical University, Institute of Architecture and Civil Engineering, 194, \\ Molodogvardeyskaya St., 443001, Samara, Russia
}

\begin{abstract}
The article is devoted to analysis of tendencies and advanced technologies in the field of energy supply and energy efficiency of tall buildings, to the history of the emergence of the concept of "efficiency" and its current interpretation. Also the article show the difference of evaluation criteria of the leading rating systems LEED and BREEAM. Authors reviewed the latest technologies applied in the construction of energy efficient buildings. Methodological approach to the design of tall buildings taking into account energy efficiency needs to include the primary energy saving; to seek the possibility of production and accumulation of alternative electric energy by converting energy from the sun and wind with the help of special technical devices; the application of regenerative technologies.
\end{abstract}

\section{Introduction}

High-rise construction, as the most progressive direction of the construction is particularly focused on the use of innovative technologies. For architects, designers and engineers of highrise buildings are ideal experimental platform for testing different decisions of the construction of the tallest, the most stable, the cheapest, the lightest, the most efficient or greenest skyscrapers. The theme of this article is to analyze trends and advanced technologies in the field of energy supply and energy efficiency of tall buildings.

Energy efficient buildings owe their birth to the first global energy crisis in 1973. Humanity first began to think about the depletion of energy resources of the planet and energy conservation. At this stage it was seeking ways to reduce energy consumption for heating of buildings. The first experimental building for testing and identifying the best technical solutions for energy saving was built in Manchester (USA). It was an office building, designed by order of the General services Administration. The energy consumption of the building was reduced by the efficient use of solar radiation, double-layer fencing structures and computer control of engineering equipment of buildings [1-3]. The implementation of this project marked the beginning of the construction of energy efficient buildings around the world. Construction of the houses with low energy consumption are successfully implemented in Europe. According to various sources, Western European countries have already built about 10 thousand of such homes. Denmark, Germany and Finland are the leaders of this movement. In these countries

\footnotetext{
*Corresponding author: auzhigulina@mail.ru
} 
the state programs of energy saving and construction of energy efficient buildings are accepted [4]. At the present stage the concept of "energy conservation" has expanded and turned into a notion of "efficiency". It implies a close intertwining of economy and ecology: people save resources and care about the environment [5]. The main principles of energy-efficient construction are maximum using of alternative renewable sources of energy such as thermal energy of earth, energy of sun, wind, and reducing the negative impact on the environment.

The presented research is part of study of modern trends of high-rise construction conducted by the Department ARPB IAC SamGTU [6-17].

\section{Methods}

Energy saving as the first stage of energy efficiency, involves a set of innovative architectural, structural and engineering measures to reduce consumption and the rational use of energy used for lighting, heating, ventilation, air-conditioning, operation of elevators, while maintaining a comfortable microclimate in the premises. It is known that heating, ventilation, air-conditioning of high-rise buildings require about $70 \%$ of energy, lighting $20 \%$, maintenance of elevators - $10 \%$. The relevance of this direction is determined by the growth of energy consumption of cities in the urbanization process. According to modern statistics, about $40 \%$ of extracted fuel in the world is spent on energy supply of buildings today.

The reduction in energy consumption can be achieved by the use of enclosing structures with optimal thermal characteristics for the climate zone of the construction site, the maximum use of reserves of natural lighting of premises with the use of larger windows. This is supported by the use of automated systems for climate control, reducing the temperature of the indoor air in the absence of people in the room; the device of night ventilation during the warm period of the year; installation of systems with variable air flow; the use of process heat to heat the cold zones and other activities [3,18].

Second, environmental, stage of efficiency - the use of alternative, renewable energy sources - solar collectors, heat pumps, wind power, thermal energy of the earth, biotechnology, etc [19].

There are several systems of rating the energy and environmental performance of buildings in the world. These systems form the standards of quality for the modern construction industry today. The most famous are the British BREEAM (Building Research Establishment Environmental Assessment Method) operating since 1990 and the us system LEED (Leadership in Energy and Enviromental Design) introduced in 1998. Both systems are rating, but the difference in approaches is that the LEED system is largely assesses the energy efficiency of buildings, and BREEAM - ecology efficiency [20-22].

The BREEAM standard differs by flexibility and adaptability to local norms and practices of construction, and LEED rigidly reglamentary using only US standards of certification and evaluation of materials. Therefore, the buildings received the BREEAM certificate may differ in the set of applied environmental elements. The buildings certified by LEED are easy to compare, since the demands of base level are standard.

BREEAM is created by the British state organization BRE Global together with the market participants. The BREEAM scheme of rating is popular not only in the UK. A version for the Gulf countries, the Netherlands, Spain, Norway, Sweden and Germany is developed now. More than 200000 projects are certified and more than a million of registered buildings still have to go through this process today. The LEED system was developed by United States Green Building Council (USGBC) as a standard of measurement for projects of energy efficient, environmentally friendly and sustainable buildings for transition to the design, construction and operation of such buildings in the construction industry. About 278,7 million $\mathrm{m}^{2}$ of built-up area were designed according to the LEED system today. The LEED 
system has expanded today, and is used as the design of new buildings and renovation of existing. The modern version of LEED - v4 (10.2013) includes 9 criteria in the field of design, construction and operation of buildings. Certification occurs at the stages of design, construction and reconstruction.

\section{Results}

Let's consider several buildings, leading in the field of energy efficiency.

Skyscraper CIS Tower in Manchester (England) is lined with more than 7,000 solar panels that produce up to 180 megawatt-hours of electricity per year. The roof is equipped with wind turbines that produce about $10 \%$ of the energy needed by the building.

Pearl River Tower, Guangzhou, China. 310-meter 71-storey building has a zero energy consumption from the external network. The South facade is supplied by double-glazed windows with ventilation between the panes to reduce heat of the building and the cost of air conditioning. Automatic blinds are rotated, depending of the angle of incidence of the sun rays, in the right direction. Tanks for rain water cleaning and recirculation are on the roof. Giant vertical wind turbines are inside the building on the technical floor. Photovoltaic panels and solar thermal collectors heat the water in the tower. According to lead architect Gordon, it is not just a building but a "high-performance tool that is generated by sun and wind." Together with architect Adrian Smith and engineer Roger Frechette Gill made a clear structure, in which the authors used virtually all of the technologies commonly used in green houses. For example, flooring is a system where circulates chilled liquid. Thus air conditioning is functioning. The engineers managed to avoid the bulk of the networks wich forced air cooling. The dehumidification system is also organized in a hidden ventilation shafts, where is situated a passive dehumidifier that removes excess moisture without the involvement of energy resources. Dry hot air will flow out of channels organized between the double glazing of the South facade. This vent glass will also reduce the overall heating of the building and, as a consequence, the cost of air conditioning.

Bank of America Tower (New York). 366-meter skyscraper made from recycled materials (used concrete with blast furnace slag). There is provided a system of accumulation and purification of rainwater, which save up to 30 million gallons of water per year.The facade is lined by the glass, which absorbes the solar radiation but provides maximum natural light. Double glazing reduces heat loss, thus reducing energy consumption. Autolighting system is regulated depending on the time of day. The cooling system produces ice reserves during the night hours to use its melting for cooling of the building in the morning and afternoon hours. The tower has a system that can produce $4.6 \mathrm{MW}$ of electricity, providing part of the requirements of a skyscraper. Powerful generators eliminate losses during transport of electricity, which are characteristic for Central supply. The cost of Bank of America Tower is 1.2 billion US dollars and $3 \%$ of the total amount are given to the sustainability of the structure. Bank of America tower is the first skyscraper, which received Platinum LEED certification.

The Bahrain World Trade Centre. 240-metre complex of dual towers, located in Manama, Bahrain. It was built in 2008 by the Atkins construction firm. There are air bridges, using wind turbines in the design of these towers. The project has passed several inspections for compliance with environmental requirements. Two towers are connected by three bridges, each with a $225 \mathrm{~kW}$ wind turbines with a total capacity of $675 \mathrm{~kW}$. Each of these turbines with a diameter of 29 meters is oriented to the North, bacause from the side of the Persian Gulf the wind blows largest number of days in a year. The towers in the shape of ships were designed in the shape of the tunnel, causing the wind passing through the tunnel, to accelerate and pass through the turbine. Beneficial use of the tunnel between the towers forming Sshaped flow was confirmed by tests showing that any wind coming at an angle of $45^{\circ}$ to each 
side of a Central axis will create a wind flow perpendicular to the turbines, which increases their potential for power generation. Wind turbines are designed to produce up to 1,100 MW of electricity per year, enough for functioning of all offices. This high energy efficiency is achieved by architectural and compositional form of the entire structure, allowing to create an accelerated airflow for the giant turbines. The turbines were included for the first time on 8 April 2008 and are designed to work $50 \%$ of time daily.

Architects of Singapore Bureau WOHA, Richard Hassell and Wong Mun Summ in the course of its successful practice in the Asia-Pacific region has offered the concept of ecological breathable skyscrapers - high-rise residential buildings. WOHA architects were thinking about how to create a cottage settlement in a vertical format, and they succeeded. Located in the capital of Thailand Bangkok 69-storey residential building The Met has become a symbol of a new vision of tropical skyscrapers. Three towers with residential units are combined by bridges transitions with gardens and swimming pools every five floors. Perforated facade ignores the wind that now walks around the apartment blocks, winding through them without the aid of mechanical systems due to the bioclimatic planning of the blocks facing North and South. Structural design ensure the safety of the air tunnel on the court between the towers, for the people in case of fire or other emergency can leave the building through two adjacent towers. Shared pools in the open air between the towers, highrise gardens, a green facade and balconies create pockets of nature even in the concrete jungle of Bangkok. Lifestyle, opened to outdoor environment and people, is possible thanks to landscape design large pool in the base unit, located there recreational areas, picnic grounds, halls for meetings or library, that allows to hold business or private meetings without leaving home from his own apartment in the green skyscraper.

Even more grandiose in area greening project implemented WOHA is located in Singapore. Residential complex Newton Suites breaks the traditional image of a polished high-rises, his shaggy paths are set at an angle sunproof metal grid, which does not block the view down. Protruding air terraces with airgardens, multi-storey vertical garden and living roof create the total area of landscaping equal to $130 \%$ of the building footprint the horizontal area, what neutralizes its impact on the environment, carrying the function of regulation the indoor climate in premises with through ventilation. Surface Parking with natural lighting and ventilation is much more energy efficient than the underground, and the exhaust gas is absorbed by covering Parking with plants. Sports club, entertainment area and pool are situated above parking.

\section{Discussion}

Green technologies provide the ability to use energy resources effectively, to construct buildings more favourable from the point of view of the health of the people, to create a favourable environment and reduce operating costs. In environmentally friendly, so-called "green" buildings are applied engineering systems and technologies to increase the efficiency of resource use - energy, water and materials. At the same time technologies in these structures, are aimed at reducing the harmful effects of building on human health and the environment during the whole cycle of its existence. This is achieved by selecting the best construction, thoughtful design and construction solutions through operation, maintenance and removal of waste products. The practice of constructing high-rise buildings shows that the energy efficiency of buildings is achieved by implementation of primary energy savings and finding opportunities in the production and accumulation of alternative electric energy.

The variety and amount of creative and technological possibilities of modern architecture is so great, that allowes architects to make the right choice in favour of universal values and global objectives. Despite the limiting nature of each concept, the principles of sustainable architecture, including, of course, energy efficiency, do not stifle, but rather relieve the 
imagination of the creators. In order not to be stymied in the search for aesthetic decision or the desire for basic functionality you must first imagine a better future world, and only then to pave the path towards him.

\section{Conclusions}

Used in the construction of high-rise buildings energy efficient strategies and technologies are evolved. Approbated at these sites optimized and effective methods need to enter into the practice of mass construction. Currently a promising vector for the development of energy efficient technologies is creating of "green" skyscrapers. This term refers to the use of construction technologies that use a variety of natural forms and resources to create healthy and comfortable conditions for human life. From the point of view of energy consumption, you must strive to create a passive (less than $45 \mathrm{kWh} / \mathrm{m}^{2}$ ) buildings and buildings with zero energy consumption (less than $15 \mathrm{kWh} / \mathrm{m}^{2}$ ). Innovative systems of bioclimatic design of tall buildings are designed to create more comfortable conditions for people's lives without the use of complex and costly technological solutions. The use of renewable energy sources is a symbol of developing technologies of the future.

\section{References}

1. Y. A. Tabunschikov, M. M. Brodach, N.V.Shilkin, Energy Efficient Buildings ( Moscow, 2003)

2. Y. A. Tabunschikov, Building materials, equipment, technologies of XXI century, 4, 22$23(2002)$

3. V. P. Generalov, Features of design of high-rise buildings (Samara, Kniga, 2007)

4. DIRECTIVE 2010/31/EU OF THE EUROPEAN PARLIAMENT AND OF THE COUNCIL of 19 May 2010 on the energy performance of buildings (recast). Official Journal of the European Union, 18.6.2010, L 153/13

5. N. A. Lekareva, Urban Construction and Architecture, 1, 6-9 (Samara, Vestnik State University of Architecture and Civil Engineering, 2011)

6. E. M Generalova., V. P. Generalov, Modern trends in architecture. High-rise residential complexes as a form of mass affordable housing (for example, Hong Kong) proceedings of Samara center of the Russian Academy of Sciences 16, 2(2), 458-463 (2014)

7. E. Generalova, V. Generalov, Designing High-Rise Housing: The Singapore Experience CTBUH Journal. Chicago, Illinois Institute of Technology, 4, 40-45 (2014)

8. V.P. Generalov, E. M. Generalova, Prerequisites for the formation of complexes of highrise social housing in Hong Kong, Traditions and innovations in construction and architecture: materials of the 71st anniversary all-Russian scientific-technical conference on the results of the NIR 2013, 379-380 (Samara, 2014)

9. A. Yu. Zhigulina, Hygiene factors in the design of high-rise buildings Traditions and innovations in construction and architecture: materials of the 71-th all-Russian scientific-technical conference on the results of the NIR 2013 - Samara state architectural-p., 384-385 (Univ. of Illinois, Samara, 2014)

10. A. Yu. Zhigulina, Urban Construction and Architecture, 1, 29-30 (Samara, Vestnik State University of Architecture and Civil Engineering, 2011)

11. V. P. Generalov, E. M. Generalova, Urban Construction and Architecture, 1(18), 13-18 (Samara, Vestnik State University of Architecture and Civil Engineering, 2015)

12. V. P. Generalov, E. M. Generalova, Scientific review, 3, 163-167 (2015)

13. E. M. Generalova, V. P. Generalov, Scientific review, 11, 46-51 (2015) 
14. E. M. Generalova, V. P. Generalov, Flats in skyscrapers. Penthouse - planning features and innovations Traditions and innovations in construction and architecture. Architecture and design: a collection of articles, 40-45 (Samara, 2015)

15. E. Generalova, V. Generalov, Apartments in Skyscrapers: Innovations and Perspectives of their Typology Development, Proceedings of the CTBUH 2015 International Conference "Global Interchanges: Resurgence of the Skyscraper City». New York, USA. 26th-30th October 2015, 355-362 ISBN: 978-0-939493-44-9. (2015)

16. A. Yu. Zhigulin, A. M. Ponomarenko, the Construction of energy efficient houses in Russia Traditions and innovations in construction and architecture. Architecture and design: a collection of articles, 90-94 (Samara, 2016)

17. A. Yu. Zhigulina, Urban Construction, 2, 84-84 (2012)

18. M. M. Brodach, Engineering equipment of high rise buildings (Moscow, 2003)

19. V. I. Ivanov, I. A. Bakhtina, T. Yu. Ivanova., S. V. Ilyin, Urban Construction and Architecture, 2(19), 88-93 (Samara, Vestnik State University of Architecture and Civil Engineering, 2015)

20. A. Gutkin, LEED rating system for energy efficient and environmentally friendly buildings, AVOK, 6 (2008)

21. BREEM - now in Russia. Green buildings J., 1 (2012)

22. A. Koryagina, Certification System of green building. Commercial Property J.,2 (91) (2011) 